DOI https://doi.org/10.36059/978-966-397-117-9/286-308

\title{
GUARANTEEING AND PROTECTING HUMAN RIGHTS AND FREEDOMS IN UKRAINE
}

\section{Fedorenko V. L.}

The publication is accustomed to the actual problems of the theory and practice of guaranteeing and protecting fundamental human rights and freedoms in Ukraine, taking into account the positive experience of human rights protection in the member states of the EU, USA and other countries of the world. It is noted that today the issue of approving, guaranteeing and protecting human rights and freedoms remains a key paradigm of law and an indicator of the effectiveness of the rule of law in a particular state.

For the newest Ukraine, the most dramatic have been the consequences of the mass violation of the fundamental human right to life and other constitutional rights (political, economic, social, cultural, religious and information, etc.) in the annexed Autonomous Republic of Crimea and the East of Ukraine during 2014-2019. So the UN in the beginning of 2019 officially increased its estimate of the number of victims of the war in the east of Ukraine to 13,000.

In this sense, the rights, freedoms and rights enshrined in the constitutions are important for a person, a society and a state in Ukraine, but also an effective guarantee of their implementation as implementation, use and observance. Achieving this goal involves combining the efforts of the state and civil society for the proper establishment, guaranteeing and protecting human rights and citizens in accordance with international standards in the field of human rights protection.

The article substantiates the position that the guarantees of constitutional human rights and freedoms and the protection of constitutional rights and freedoms are related, but not identical categories. If the guarantees of constitutional rights and freedoms of man are, first of all, is a system of conditions and means for the effective realization of human rights and freedoms, then their protection is an independent form of legal activity, the content of which is the purposeful and systemic activity of the person, society and the state with regard to extrajudicial and 
judicial protection and the restoration of already violated constitutional rights and freedoms.

It is determined that under the guarantees of constitutional rights and freedoms should be understood the system of conditions and means, legal mechanisms for ensuring the proper realization of the rights and freedoms of man and citizen determined by the Constitution and laws of Ukraine. At the same time, the system of guarantees of constitutional rights and freedoms in Ukraine is represented by general and special (legal) guarantees.

In its turn, the general guarantees of human rights and freedoms are determined by the level of development of the main spheres of social and public life like political, economic, social, cultural (spiritual), informational and ecological, etc. Special, legal guarantees of constitutional rights and freedoms in Ukraine are represented, first of all, by legal and regulatory (legislative) and organizational and legal (institutional) mechanisms of realization of these rights and freedoms interconnected among themselves. The specified general and special guarantees do not work effectively alone without the others.

It is emphasized that the organizational and legal (institutional) guarantees of human rights and freedoms in Ukraine are represented by the system of the main subjects of constitutional law, which covers the followings: (1) the people of Ukraine; (2) territorial communities; (3) bodies of state power and bodies of local self-government, their officials and officers; (4) political parties; (6) civil society and its institutions; and (7) citizens of Ukraine and others. These subjects of constitutional law are authorized in their activities to establish and guarantee constitutional rights and freedoms everywhere.

Unlike guarantees, the protection of constitutional rights and freedoms of a person and a citizen is an independent form of purposeful legal activity and a process of human rights protection, which is carried out by specially authorized subjects in judicial and extrajudicial way at the national and international level. The main kind of protection of constitutional rights and freedoms in Ukraine and abroad is theirs judicial protection. According to Art. 55 of the Constitution of Ukraine judicial protection of human and civil rights and freedoms is carried out by the system of courts of general jurisdiction of Ukraine. The state guarantees every person the right to appeal in court decisions, actions or inactivity of 
state authorities, local self-government bodies, officials and officers who violate the rights and freedoms of man and citizen.

In addition to the judicial protection of constitutional rights and freedoms, an extensive system of their extra-judicial protection is operating in Ukraine through bodies of state power and bodies of local self-government, their officials, as well as through civil society institutes. Thus, according to the Basic Law, the Verkhovna Rada of Ukraine has exclusive powers to regulate the rights and freedoms of citizens and guarantee their implementation (Art. 92); the President of Ukraine is the guarantor of the rights and freedoms of man and citizen (Art. 102); and the Cabinet of Ministers of Ukraine takes measures to ensure the rights and freedoms of man and citizen (Art.116) and involves a system of executive bodies.

Ukraine also has a system of specially authorized state agencies to carry out human rights activities of the subjects: the Ukrainian Parliament Commissioner for Human Rights and the system of specialized 'ombudsmen' formed under the head of state and government as follows: (1) the Authorized President of Ukraine on the rights of the child; (2) Commissioner of the President of Ukraine of the Crimean Tatar people; (3) Commissioner of the President of Ukraine on the rights of people with disabilities; 4) Commissioner of the President of Ukraine of rehabilitation of participants of the Antiterrorist Operation (ATO) who received injuries, contusions, injuries or other illnesses during participation in the Antiterrorist Operation; (5) Government Commissioner for European Court of Human Rights; 6) Governmental Commissioner for Gender Policy; (7) Governmental Commissioner for People with Disabilities; and (8) Council of the Business Ombudsman under the Cabinet of Ministers of Ukraine and others.

In addition to the state, the institutions of civil society play an important role in protecting constitutional rights and freedoms. First and foremost, domestic and international human rights organizations.

\section{Constitutional Rights and Freedoms of Man as a Universal Value that needs Effective Protection}

It is generally acknowledged that human rights and freedoms are one of the most important values for societies and states around the world. It was these human rights and freedoms that became the main motto of the 
first revolution in the end of 18th-19th centuries and after their victory became the heart of the White and the declarations of human rights, constitutions and constitutional acts initially states of Europe and America, Japan, and in the future and other parts of the world ${ }^{1}$.

Most of the founders of classical American and European constitutionalism drew attention to the significant impact of human rights and freedoms on the law as a whole. So, the famous American thinker A. de Tocqueville wrote about human rights the following:

'The noblest notion of virtue is the concept of rights. Suffice it to say, both of these concepts are interconnected: rights are nothing but virtues transposed into political life, ${ }^{2}$.

Today, like two or three centuries ago, the issue of the establishment, guaranteeing and protecting human rights and freedoms remains a key paradigm of law and an indicator of the effectiveness of the rule of law in a particular state. It is obvious that not only the scope of the rights and freedoms enshrined in the constitutions is important to man, society and state, but the reality of their implementation: implementation, use and observance. In this sense, the Charter of Fundamental Rights of the European Union (2000) in its Preamble consolidated the following relevant provisions:

'The European Union promotes the preservation and development of common values while respecting the diversity of cultures and traditions of the peoples of Europe... it seeks to promote balanced and steady development and ensures the free movement of persons, goods, services and capital, as well as freedom of establishment of business entities. To this end, it should be by giving them the Charter greater certainty, strengthening the protection of fundamental rights, taking into account the evolution of society, social progress, the development of science and technology, 3 .

Thus, the Charter of Fundamental Rights of the European Union emphasizes the need, on the one hand, to strengthen the normative definition of human rights and freedoms, on the other hand, to strengthen mechanisms for the protection of these rights and freedoms, taking into account the achievements of social progress, and science and technology.

\footnotetext{
${ }^{1}$ Федоренко В.Л. Конституціоналізм і революції / В.Л. Федоренко // Право України. - 2018. № 4. - С. 73 .

2 Токвіль А. де. Про демократію в Америці. У двох томах / А. де Токвіль ; пер. 3 фр. Г. Філіпчука та М. Москаленка : передм. А. Жардена. - К. : Вид. дім «Всесвіт», 1999. - С. 198.

3 Хартия основных прав Европейского Союза. [Електронний ресурс]. - Режим доступу : http: zakon5.rada.gov.ua/laws/show/994_524 - назва з екрана.
} 
This will allow you to focus the efforts of the societies and member states of the EU and other European states to protect primarily fundamental human rights and freedoms and to abandon irrational 'competitions' for the formal expansion of the nomenclature and the scope of positive human rights in the 21 st century that states cannot guarantee and protect at the present stage of their development.

Such an approach to the establishment and protection of fundamental rights and freedoms in the EU is also relevant today. After all, the migration crisis and the mixed consequences of the policy of multiculturalism in the last 10 years in the European Union have aggravated the problem of the ability of states to effectively ensure the rights of people to a decent material standard of living, work and leisure, social protection and a number of others.

It is obvious that the approval and implementation of constitutional rights and freedoms in the 21st century depends on the perfection of the general social and legal mechanisms of their guarantee and protection. The relevant issues, given the 2014 Independence Revolution and its subsequent annexation of the Crimea and the fighting in the East of Ukraine in 2014-2019, today are relevant for our state. After all, ensuring the realization, guaranteeing and protecting human rights and freedoms for the relevant tasks is not only an important but also a complex task for the state, civil society and human rights activists, including international profile organizations.

Thus, one of the fundamental values of the Revolution of Dignity, from which its name derives, has become dignity, which is recognized as the core of the system of human rights and freedoms in all democratic states. Fixed in Art. 1 of the Universal Declaration of Human Rights (1948), the provision that stipulates the following: 'All men are born free and equal in their dignity and rights' ${ }^{4}$ according to S. Holovatyi, confirmed the 'concept of humanity as a synthesis of ideas and values that are direct sprouts of the great ideas of the age of Enlightenment and the famous practical achievements of the American and French Revolutions, ${ }^{, 5}$.

Violations of human dignity have become the prerequisite for many revolutions in the world, beginning with the Glory Revolution in 1688 in England and before the revolutions of the 21st century, including the Revolution of Dignity. As you know, on November 30, 2013, during the

\footnotetext{
4 Загальна декларація прав людини : прийнята та проголошена резолюцією Генеральної Асамблеї ООН від 10 грудня 1948 року № 217 А (III) // Офіційний вісник України. - 2008. - № 93. - Ст. 3103.

${ }^{5}$ Головатий С. Про людські права. Лекції / С. Головатий. - К. : Дух і літера, 2016. - С. 433.
} 
forceful dispersal of the Euro-Maidan revolution, the special forces of the Berkut militia (Police) roughly violated the guaranteed in Art. 3 of the Basic Law the right of protesters to dignity. Then, for the second time in the 21st century, after the Orange Revolution, Ukrainians resorted to the effective public defence of their human dignity and other fundamental human rights and freedoms. However, the price of the victory of the Revolution of Dignity was too high.

The Commissioner of the Verkhovna Rada of Ukraine for Human Rights, in his annual report on the state of observance of human rights and freedoms in Ukraine, noted that during the Revolution of dignity in the period from January 1 to February 22, 2014, 105 people died in Kyiv due to events in the Independence Square in Kyiv (of them 94 people during clashes on Instytutska Street). The overwhelming number of fatal cases was associated with the acquisition of firearms ${ }^{6}$.

In the future, the annexation of the Autonomous Republic of Crimea and the temporary occupation of certain districts of Donetsk and Luhansk Oblasts (regions), the ATO, massive forced internal migration of Ukrainians (internally displaced persons), as well as the large-scale military-political, socio-economic and humanitarian crisis in 2014-2019, are made to be critical rethink existing safeguards and mechanisms for the protection of constitutional rights and freedoms in Ukraine, which the author has already written earlier ${ }^{7}$.

But the most severe have been the consequences of mass violations of the fundamental human right to life in the East of Ukraine during 20142019. So the UN in the beginning of 2019 officially increased its estimate of the number of victims of the war in the East of Ukraine to 13,000. Of these, a quarter is civilians, and more than 30,000 are injured. This figure also includes 298 Boeing passengers on the MH17 Flight of the Malaysia Airlines, which was shot down on July 17, 2014 in the sky over the Donbas on the way from Amsterdam to Kuala Lumpur. This was reported

\footnotetext{
${ }^{6}$ Щорічна доповідь Уповноваженого Верховної Ради України з прав людини про стан додержання та захисту прав і свобод людини і громадянина в Україні. - К., 2015. - С. 9-13.

${ }^{7}$ Федоренко В.Л. Конституційне право України : підручник ; До 20-ої річниці Конституції України та 25-ої річниці незалежності України / В.Л. Федоренко. - К. : Вид-во «Ліра», 2016. - С. 258; Fedorenko W. Efektywność ochrony praw i wolności człowieka w Ukrainie: historia, współczesność, perspektywy / W. Fedorenko // Uniwersalny i regionalny wymiar ochrony praw człowieka. Nowe wyzwania - nowe rozwiązania. - T. 3. - Warszawa: Wydawnictwo Sejmowe, 2014. - S. 803-806.; Fedorenko W. Problem ochrony praw człowieka w warunkach rewolucji oraz konfliktów wojennych / W. Fedorenko // Ochrona praw człowieka w wymiarze uniwersalnym. Akcjologia - instytucje - nowe wyzwania - praktyka. Red. naukowa J. Jaskiernia, K. Sprzyszak. - Toruń: Wydawnictwo Adam Marszałek, 2017. - S. 73-79
} 
by the Office of the United Nations High Commissioner for Human Rights in a document dated February 25, $2019^{8}$.

However, violation of the right to life, human dignity and other personal rights and freedoms of people in Crimea and East of Ukraine in 2014-2019 does not exclude violations of other political, economic, social, cultural, and information rights and freedoms. For several years in a row, in the annual report of the Ukrainian Parliament Commissioner (Ombudsperson) for Human Rights on the state of observance and protection of human and civil rights and freedoms in Ukraine, the first and, accordingly, the priority section is the section on the observance of the rights and freedoms of internally displaced persons and persons living in the temporarily occupied territory. First of all, this report refers to the right to receive payments and benefits guaranteed by the state, property rights and legal personality, suffrage, right to freedom of movement, and access to education, etc. ${ }^{9}$

In connection with the situation described in the field of fundamental human rights and freedoms in Ukraine, the issue of guaranteeing and protecting constitutional rights and freedoms in Ukraine becomes of paramount importance for constitutional doctrine, law-making and lawenforcement practice. Obviously, under Ukraine cannot abandon its international obligations in the field of human rights and freedoms and unilaterally reduce the range of guaranteed human rights and freedoms under any circumstances. Consequently, the only constructive way to resolve this problem is to strengthen safeguards and to improve mechanisms for the protection of constitutional rights and freedoms, taking into account the positive experience of the states of Europe (Poland, Romania, Croatia and Montenegro, etc.) who survived the revolution and military conflicts.

The theoretical and methodological foundations of guaranteeing and protecting constitutional rights and freedoms demand for their rethinking. Most Ukrainian lawyers believe that an important element of the constitutional and legal status of a person and a citizen is the guarantees of these rights and freedoms ${ }^{10}$, or their provision ${ }^{11}$ or protection as a 'concept

\footnotetext{
${ }^{8} 13$ тисяч: офіційні дані ООН щодо загиблих у війні на Донбасі / Радіо Свобода. [Електронний pecypc]. - Режим доступу : https:/www.radiosvoboda.org/a/29792144.html - назва з екрану.

9 Щорічна доповідь Уповноваженого Верховної Ради України з прав людини про стан додержання та захисту прав і свобод людини і громадяина в Україні. - К. : Вид.- поліграф. центр «Київськ. ун-т», 2018. - С. 10-26.

10 Заворотченко Т. М. Конституційно-правові гарантії прав і свобод людини і громадянина в Україні: Автореф. дис. ... канд. юрид. наук. - К., 2002. - 19 с.
} 
of human rights ${ }^{12}$ and offer their own scientific approaches to their definition. The most traditional, though not exhaustive, for the science of constitutional law, remains the category of 'guarantees of constitutional rights and freedoms' for today.

The guarantees of constitutional human rights and freedoms and the protection of constitutional rights and freedoms are related, but not identical categories. If the guarantees of constitutional rights and freedoms of man are, first of all, is a system of conditions and means for the effective realization of human rights and freedoms, then their protection is an independent form of legal activity, the content of which is the purposeful and systemic activity of the person, society and the state with regard to extrajudicial and judicial protection and the restoration of already violated constitutional rights and freedoms. That is, the guarantees of human rights and freedoms are the conditions for their approval and implementation, and protection is the activity to restore these rights and freedoms.

At the same time, guaranteeing and protecting human rights and freedoms are complementary phenomena. Consider them as mutually determined phenomena of constitutional and legal being.

\section{Guarantees of Constitutional Rights and Freedoms in Ukraine: Concept, Content and System}

It is determined that under the guarantees of constitutional rights and freedoms should be understood the system of conditions and means, legal mechanisms for ensuring the proper realization of the rights and freedoms of man and citizen determined by the Constitution and laws of Ukraine.

At the same time, the system of guarantees of constitutional rights and freedoms in Ukraine is represented by general and special (legal) guarantees. In its turn, the general guarantees of human rights and freedoms are determined by the level of development of the main spheres of social and public life like political, economic, social, cultural (spiritual), and informational and ecological, etc. ${ }^{13}$

Political guarantees of constitutional rights and freedoms include, first and foremost, such major political institutions as the Institute of

\footnotetext{
${ }^{11}$ Пушкіна О. В. Конституційний механізм забезпечення прав людини і громадянина в Україні: проблеми теорії і практики: Автореф. дис. ... док. юрид. наук. - Х., 2008. - 48 с.

${ }_{12}$ Корнієнко П.С. Конституційні основи правозахисної діяльності в Україні : монограф. / П.С. Корніснко. - К. : Видавництво Ліра-К, 2018. - 360.

${ }_{13}$ Федоренко В.Л. Конституційне право України : підручник ; До 20-ої річниці Конституції України та 25-ої річниці незалежності України / В.Л. Федоренко. - К. : Вид-во «Ліра», 2016. - С. 260.
} 
People's Sovereignty, forms of direct democracy, political and ideological pluralism, and multi-party system, etc. Equally important political guarantee of guarantees of human rights and freedoms is the development of civil society and its institutions, the growth of 'social capital' and the expansion of social human rights networks, the development of participative democracy and the parity of civil society and state cooperation in the human rights sphere.

Economic guarantees of constitutional rights and freedoms are represented by property institutions, economic pluralism, freedom and security of entrepreneurial and economic activity, etc. It is well-known that property generates and, at the same time, guarantees the fundamental rights and freedoms of man. It is significant that in the 19th century in the states of Western Europe and the United States, citizens who did not have private property and did not pay taxes were limited to individual rights. The same development and protection by the state and society of all forms of ownership is an important condition for the construction of a 'society of owners', in which everyone understands and recognizes the limits of their own rights and freedoms ${ }^{14}$.

Social guarantees of constitutional rights and freedoms presuppose the existence of a developed social, but not populist and not paternalistic state. The socially responsible state must firmly provide its citizens, all the people who are legally in its territory with the opportunity to dignify the results of their work, as well as enjoy social protection of the state, due to objective circumstances as disability, retirement, temporary loss of ability to work, forced displacement within the state, etc.

Cultural (spiritual) guarantees of constitutional rights and freedoms are expressed in the presence of effective mechanisms for supporting the development of national culture and national minority culture. Equally important, the spiritual guarantee is respect for fundamental human rights and freedoms, both to the traditional spiritual values of civil society and every single person.

There are other types of general guarantees of constitutional rights and freedoms of man and citizen in Ukraine. Thus, in recent years in Ukraine, open and unbiased information on the essence and content of such rights, forms and methods of their realization, as well as guarantees and methods of protection, is of great importance for the consolidation of

\footnotetext{
14 Федоренко В.Л. Конституційне право України : підручник ; До 20-ої річниці Конституції України та 25-ої річниці незалежності України / В.Л. Федоренко. - К. : Вид-во «Ліра», 2016. - С. 260.
} 
human rights and freedoms. In this context, the National Educational Human Rights Project of the Ministry of Justice of Ukraine deserves attention: 'I have a right! I know! I act! I protect! '15.

In addition, the annual reports of the Ukrainian Parliament Commissioner for Human Rights on compliance with constitutional rights and freedoms, as well as the results of monitoring of the state of human rights and freedoms in Ukraine carried out by civil society institutions, allow one to resist the 'hybrid war' which is a thesis about the not-soiled mythical 'massive violations of human rights by the state bodies in Ukraine' and, at the same time, to analyse the weak links of human rights activism in Ukraine, find ways to strengthen and upgrade them.

The general guarantees of the constitutional rights and freedoms of a person have a significant impact on their implementation, since they confirm the readiness of man, society and state to realize the rights and freedoms. Any, even the most perfect legal mechanism for the implementation of constitutional rights and freedoms is powerless, provided the low level of political and socio-economic development of civil society and the state, the absence of established traditions of legal culture, and intolerance to corruption, etc.

At the same time, general guarantees cannot replace or replace the conditions created by law for optimal realization of human rights and freedoms. After all, it is the Constitution and laws of Ukraine that give us the most complete, though not exhaustive, idea of the content and scope of human rights and freedoms, mechanisms and procedures for their implementation and protection, as well as determine the system of entities authorized to ensure their approval and guarantee: from the state to such reputable international organizations as the United Nations (UN).

Special, legal guarantees of constitutional rights and freedoms in Ukraine are represented, first of all, by legal and regulatory (legislative) and organizational and legal (institutional) mechanisms of realization of these rights and freedoms interconnected among themselves.

Legal and regulatory guarantees of the basic rights and freedoms of man and citizen are represented by a system of norms of constitutional law, which establish and fix the basic rights and freedoms, define the principles, forms, methods, mechanisms and procedures for their implementation. These guarantees are objectively reflected in the system

\footnotetext{
15 «Я маю право!» / офіційний веб-сайт Міністерства юстиції України. [Електронний ресурс]. Режим доступу : https://pravo.minjust.gov.ua/ua - назва з екрану.
} 
of current legislation of Ukraine in the field of human and civil rights and freedoms, namely, in the Constitution of Ukraine, the laws of Ukraine, and other acts of the current legislation ${ }^{16}$.

Thus, the Constitution of Ukraine establishes general principles of legal and regulatory guarantees. In particular, Art. 57 of the Basic Law determines that laws and other legal and regulatory acts defining the rights of citizens must be brought to the attention of the population in accordance with the procedure established by law. Otherwise, such legal and regulatory acts are not valid ${ }^{17}$.

At the same time, the constitutional rights and freedoms of man and citizen, according to Art. 64 of the Basic Law, stipulated by Articles 24, $25,27,28,29,40,47,51,52,55,56,57,58,59,60,61,62$ and 63 , may not be restricted except in cases where stipulated by the Constitution of Ukraine $^{18}$. Separate restrictions of rights and freedoms, indicating the validity of these restrictions, may be established solely in conditions of martial law or state of emergency. At the same time, Ukraine remains a state that, even under conditions of aggression 2014-2019, ensures the realization of the overwhelming majority of constitutional rights and freedoms, even those whose restrictions are allowed by the Constitution of Ukraine.

Despite the fact that the norms of the Constitution of Ukraine are rules of direct action, and the rights and freedoms of people, which are enshrined in the Basic Law, can be appealed in courts, the legislator in paragraph 1 of part one of Art. 92 of the Constitution of Ukraine has determined that human rights and freedoms and their guarantees are determined exclusively by the laws of Ukraine ${ }^{19}$. At the same time, a significant number of human and civil rights and freedoms have not received their development in special laws (the right to peaceful assembly), some laws that regulate the exercise of constitutional rights of citizens have ceased to exist for the 23 years since the adoption of the Constitution of Ukraine. For example, the legislation on all-Ukrainian and local referenda.

\footnotetext{
16 Федоренко В.Л. Конституційне право України : підручник ; До 20-ої річниці Конституції України та 25-ої річниці незалежності України / В.Л. Федоренко. - К. : Вид-во «Ліра», 2016. - С. 261.

${ }^{17}$ Конституція України : прийнята на п’ятій сесії Верховної Ради України 28 червня 1996 року // Відомості Верховної Ради України. - 1996. - № 30. - Ст. 141.

${ }^{18}$ Конституція України : прийнята на п’ятій сесії Верховної Ради України 28 червня 1996 року // Відомості Верховної Ради України. - 1996. - № 30. - Ст. 141.

${ }^{19}$ Конституція України : прийнята на п’ятій сесії Верховної Ради України 28 червня 1996 року // Відомості Верховної Ради України. - 1996. - № 30. - Ст. 141.
} 
Prior to World War II, the protection of human rights and freedoms was seen primarily as a matter of domestic national policy. However, already the preamble to the UN Charter of 1945 has shown the joint determination of the signatory states '... to reaffirm faith in fundamental human rights, the dignity and value of the human person ... ${ }^{20}$.

Since then, in addition to the acts of the current legislation, international convention mechanisms play an exceptionally important role in guaranteeing fundamental human rights and freedoms. Such guarantees today are represented by a system of international treaties, agreements and framework conventions in the field of the establishment and protection of fundamental human and civil rights and freedoms. The main universal international acts in this area include the Universal Declaration of Human Rights of 1948, the Convention for the Protection of Human Rights and Fundamental Freedoms of 1950, the International Covenant on Civil and Political Rights of 1966, the International Covenant on Economic, Social and Cultural Rights of 1966, the International Convention on the Elimination of All Forms of Discrimination against Women of 1979, the UN Convention on the Rights of the Child of 1989, the Paris Climatic Agreement, adopted December 12, 2015, replacing the Kyoto Protocol, ratified by Ukraine in June 2016, etc. ${ }^{21} 222324252627$

\footnotetext{
${ }^{20}$ Стаття 8 Конвенції про захист прав людини і основоположних свобод: стандарти застосування при здійсненні правосуддя / Н. Ахтирська, В. Філатов, Т. Фулей, Х. Хембах. - К. : Істина, 2011. - С. 8.

${ }^{21}$ Конвенція про захист прав людини і основоположних свобод від 4 листопада 1950 року : ратифікована Законом України від 17 липня 1997 року № 475/97-ВР разом з першим протоколом та протоколами № 2, 4, 7 та 11 // Відомості Верховної Ради України. - 1997. - № 40. - Ст. 263.

${ }_{22}^{2}$ Міжнародний пакт про громадянські і політичні права від 16 грудня 1966 року : ратифікований Указом Президії Верховної Ради УРСР від 19 грудня 1973 року № 2148-VIII (з двома факультативними протоколами) // Международные акты о правах человека. Сборник документов. - М. : НОРМАИНФРА-М, 1998. - С. 53-76.

23 Міжнародний пакт про економічні, соціальні і культурні права від 16 грудня 1966 року : ратифікований Указом Президії Верховної Ради УРСР від 19 грудня 1973 року № 2148-VIII // Международные акты о правах человека. Сборник документов. - М. : НОРМА-ИНФРА-М, 1998. C. 44-52.

${ }^{24}$ Міжнародна конвенція про ліквідацію усіх форм расової дискримінації від 7 березня 1966 року : ратифікована Президією Верховної Ради Української РСР 21 січня 1969 року // Международные акты о правах человека. Сборник документов. - М. : НОРМА-ИНФРА-М, 1998. - С. 138-148.

${ }^{25}$ Конвенція про ліквідацію всіх форм дискримінації жінок від 18 грудня 1979 року : ратифікована УРСР 24 грудня 1980 року (із застереженням) // Международные акты о правах человека. Сборник документов. - М. : НОРМА-ИНФРА-М, 1998. - С. 266-280.

26 Конвенція про права дитини : 20 листопада 1989 року (редакція зі змінами, схваленими резолюцією 50/155 Генеральної Асамблеї ООН від 21 грудня 1995 року) // Зібрання чинних міжнародних договорів України. - 1990. - № 1. - Ст. 205.

27 Парижська кліматична угода, прийнята 12 грудня 2015 р. // Відомості Верховної Ради України. 2016. - № 35. - С т. 595.
} 
Regional conventions have a significant influence on the development of human rights and freedoms. For example, for Ukraine and EU member states of the EU, such a convention is today the Charter of Fundamental Rights of the European Union of $2000^{28}$. In the context of Ukraine's implementation of the Association Agreement with the EU, enacted in 2016, this international human rights document will be projected to form the senses and trends of guaranteeing and protecting human rights and freedoms in Ukraine.

Organizational and legal (institutional) guarantees of human rights and freedoms are represented by the system of the main subjects of constitutional law, which covers: (1) the people of Ukraine; (2) territorial communities; (3) bodies of state power and bodies of local selfgovernment, their officials and officers; (4) political parties; (6) civil society and its institutions; and (7) citizens of Ukraine and others ${ }^{29}$. The subjects of constitutional law mentioned above are authorized in their statutory activities (except for people and territorial communities) to establish and guarantee constitutional rights and freedoms everywhere.

Among the mentioned subjects of guaranteeing constitutional rights and freedoms in Ukraine, civil society and its institutions are becoming more and more important. First of all, it's about human rights organizations.

In turn, part 2 of Art. 57 of the Constitution of Ukraine stipulates:

'Laws and other normative legal acts defining the rights and freedoms of citizens must be brought to the jurisdiction of the population in accordance with the procedure established by law ${ }^{30}$.

Obviously, the subjects that prove to people their rights and freedoms, and such mechanisms and methods of their implementation are, first of all, public authorities and local self-government bodies, and their officials. At the same time, civil society institutions are such entities. First of all, there are human rights NGOs.

The substantiated system of guarantees of constitutional rights and freedoms in Ukraine is not flawless. This was also due to numerous violations of human rights and freedoms during the Revolution of Dignity and the conduct of the ATO (now the Joint Forces Operation (JFO)) in

\footnotetext{
28 Хартия основных прав Европейского Союза. [Електронний ресурс]. - Режим доступу : http: zakon5.rada.gov.ua/laws/show/994_524 - назва з екрана.

${ }_{29}$ Федоренко В.Л. Конституційне право України : підручник ; До 20-ої річниці Конституції України та 25-ої річниці незалежності України / В.Л. Федоренко. - К. : Вид-во «Ліра», 2016. - С. 262.

${ }^{30}$ Конституція України : прийнята на п'ятій сесії Верховної Ради України 28 червня 1996 року // Відомості Верховної Ради України. - 1996. - № 30. - Ст. 141.
} 
2014-2019. But, in peacetime, such delusions are no exception for Ukraine. This, in particular, is evidenced by the steady and stable stay of Ukraine in the last 10-15 years in the first 5 States of the Council of Europe in terms of the number of citizens' complaints to the European Court of Human Rights.

Therefore, guarantees of constitutional rights and freedoms in Ukraine, as in most countries of the world, are combined with mechanisms for their protection and renewal. For Ukraine, issues of human rights protection remain relevant.

\section{Protection of Constitutional Rights and Freedoms in Ukraine: Judicial and Extrajudicial Mechanisms}

Protection of constitutional rights and freedoms of a person and a citizen is an independent form of purposeful legal activity and a process of human rights protection, which is carried out by specially authorized subjects in court and extrajudicial mode at the national and international level $^{31}$.

The main kind of protection of constitutional rights and freedoms in the world is theirs judicial protection. According to Art. 55 of the Constitution of Ukraine judicial protection of human and civil rights and freedoms is carried out by the system of courts of general jurisdiction of Ukraine. The state guarantees every person the right to appeal in court decisions, actions or inactivity of state authorities, local self-government bodies, officials and officers who violate the rights and freedoms of man and citizen.

In the case of the use of all domestic remedies for his rights and freedoms, a person may apply to international judicial authorities, for example, to the European Court of Human Rights (ECHR). As already noted Ukraine retains dubious leadership in Europe over claims and lost cases in the ECHR.

Judicial reform, initiated with the adoption by the Verkhovna Rada of Ukraine on June 2, 2016 of the Law of Ukraine ,On Amendments to the Constitution of Ukraine (on Judicial Proceedings)", changed not only the system of courts of general jurisdiction, but also the constitutional and legal status of the advocacy. Today, part two of Art. 131-2 of the Basic Law guarantees the independence of lawyers, and part four of the same

31 Федоренко В.Л. Конституційне право України : підручник ; До 20-ої річниці Конституції України та 25-ої річниці незалежності України / В.Л. Федоренко. - К. : Вид-во «Ліра», 2016. - С. 263. 
article establishes that 'the lawyer exclusively represents the other person in court, as well as protection from criminal charges ${ }^{, 32}$.

The strengthening of the powers of the Institute of Advocacy in Ukraine in 2016-2019 as a whole contributed to improving the mechanism for the protection of constitutional rights and freedoms. At the same time, this constitutional narrative and its reflection in the current Law of Ukraine "On Advocacy and Advocacy"33 gave rise to the phenomenon of the 'lawyer's monopoly' in Ukraine, when the representation of physical and legal in courts became exclusive competence of lawyers and, in essence, limited the guaranteed in Art. 55 of the Constitution of Ukraine the right to judicial protection of a person's rights.

The practice of enforcement of judgments in the human rights sphere, which has been repeatedly emphasized in the decisions of the European Court of Human Rights on claims of citizens of Ukraine, continues to be ambiguous. So, at one time, the decision of the European Court of Human Rights on the Yurii Mykholaiovych Ivanov vs. Ukraine Case, the system of execution by the Ukrainian state of judgments in the field of human rights was extremely negative. In response to this decision, the Ministry of Justice developed a bill, and the Verkhovna Rada of Ukraine adopted the Law of Ukraine "On State Guarantees for the Implementation of Court Decisions", which came into force on January 1, $2013^{34}$.

The provisions of the Law of Ukraine „On State Guarantees for Enforcement of Court Decisions" break the pre-established practice in which the decision of the courts, primarily on the collection of funds, was often carried out with considerable delay due to the lack of a legal mechanism for the compulsory collection of funds from the state, its organs, enterprises, institutions and organizations. Now the article. 2 of this Law stipulates that the Ukrainian state guarantees execution of a court decision on collection of funds and an obligation to perform certain actions concerning property, the debtor of which is: a state body; state enterprise, institution, organization; legal entity, the forced realization of which property is prohibited in accordance with the law.

\footnotetext{
32 Про внесення змін до Конституції України (щодо правосуддя) : Закон України від 2 червня 2016 р. // Голос України. - 2016. - № 118 (від 29.06.2016).

${ }^{33}$ Про адвокатуру та адвокатську діяльність : Закон України від 5 липня 2012 р. // Відомості Верховної Ради України. - 2014. - № 50-51. - Ст. 2057.

${ }^{34}$ Про гарантії держави щодо виконання рішень суду: Закон України від 5 червня 2012 р. // Офіційний вісник України. - 2012. - №. 49. - Ст. 1919.
} 
In addition to the judicial protection of constitutional rights and freedoms, an extensive system of their extra-judicial protection is operating in Ukraine through bodies of state power and bodies of local self-government, their officials, as well as through civil society institutes. Thus, according to the Basic Law, the Verkhovna Rada of Ukraine has exclusive powers to regulate the rights and freedoms of citizens and guarantee their implementation (Art. 92); The President of Ukraine is the guarantor of the rights and freedoms of man and citizen (Art. 102); The Cabinet of Ministers of Ukraine takes measures to ensure the rights and freedoms of man and citizen (Art. 116) and involves a system of executive bodies $^{35} 36$.

The protection of human rights and freedoms is also determined by the priority tasks of law-enforcement bodies in Ukraine. Thus, item 2 of the first part of Art. 2 of the Law of Ukraine "On National Police" defines the main task of the National Police is 'the protection of human rights and freedoms ${ }^{37}$. Similar provisions are found in most provisions of the ministries and other central executive bodies. Protection of human rights and freedoms also serves as a priority both in the activities of local selfgovernment bodies and their officials.

In Ukraine, there is also a system of specially authorized state agencies for the implementation of human rights activities of entities. In addition to the institution of the Ombudsperson of the Verkhovna Rada of Ukraine on Human Rights, the procedure of which is determined by the Law ,On the Commissioner of the Verkhovna Rada of Ukraine on Human Rights" dated December 23, 1997, the system of specialized 'ombudsmen' established under the head of state and government is also in force: ${ }^{38}$

- Commissioner of the President of Ukraine on the rights of the child;

- Commissioner of the President of Ukraine on affairs of the Crimean Tatar people;

\footnotetext{
35 Конституція України : прийнята на п’ятій сесії Верховної Ради України 28 червня 1996 року // Відомості Верховної Ради України. - 1996. - № 30. - Ст. 141.

36 Корнієнко П.С. Конституційні основи правозахисної діяльності в Україні : монограф. / П.С. Корнієнко. - К. : Видавництво Ліра-К, 2018. - С. 303.

37 Про Національну поліцію : Закон України від 2 липня 2015 р. // Відомості Верховної Ради України. - 2015. - № 40-41. - Ст. 379.

${ }^{38}$ Про Уповноваженого Верховної Ради України з прав людини» від 23 грудня 1997 р. // Відомості Верховної Ради України. - 1998. - № 20. - Ст. 99.
} 
- Commissioner of the President of Ukraine on the rights of people with disabilities;

- Commissioner of the President of Ukraine on rehabilitation of participants of the antiterrorist operation who has been injured, contused, injured or other illnesses during participation in the antiterrorist operation;

- Government Commissioner for European Court of Human Rights;

- Governmental Commissioner for Gender Policy;

- Governmental Commissioner for People with Disabilities; and

- Council of the Business Ombudsman under the Cabinet of Ministers of Ukraine, and others.

The strengthening of the ombudsman system in Ukraine by the presidential and governmental authorities is, on the one hand, a positive step towards the specialization of human rights protection, and on the other, it creates competition for competences and leads to the dispersal of the forces and resources of these human rights activists.

In addition to the state, the institutions of civil society play an important role in protecting constitutional rights and freedoms. In particular, such human rights organizations as: the Ukrainian Human Rights Union, the Kharkiv Human Rights Protection Group, the Donetsk Memorial, the Coalition Against Discrimination in Ukraine, LA STRADA-UKRAINE International Women's Rights Centre, the Coalition for the Rights of the Child, the Centre for Civil Liberties, THE REGIONAL CENTER FOR HUMAN RIGHTS Civil Society, THE RIGHT TO PROTECTION All-Ukrainian Charitable Foundation and others. These civil society institutions not only protect the rights to freedom of their members and third parties, but also carry out independent monitoring of human rights and freedoms, develop proposals to improve the law-making and law-enforcement aspects of human rights activities in Ukraine.

The authors of the Civil Society in Ukraine: Current State, Challenges, Strategy for Modernization monograph (2018) write that public human rights organizations are also acting through:

....representing the interests of citizens in state authorities, exercising control over their activities, organizing the participation of citizens in solving public affairs and ensuring the transparency of these processes, promoting the establishment of social harmony through constructive dialogue with authorities, representatives of various political forces, 
national groups; documentation of violations; finding remedies for victims of such violations by providing legal, psychological, medical or other support; the fight against impunity is a phenomenon that is a breeding ground for the systematic violation of human rights and fundamental freedoms; participation in authorized and unauthorized protest actions; and the promotion of human rights and the dissemination of information on human rights defenders at the national, regional and international levels ${ }^{39}$. This quotation emphasizes the diversity of methods and forms of human rights protection in Ukraine and the world as a whole.

In case when national extrajudicial remedies for human rights have been exhausted, a person has the right guaranteed by the Constitution of Ukraine to appeal to international human rights organizations (Art. 55) ${ }^{40}$. So, today, there are the following international human rights organizations: the European Commission on Human Rights, the International Committee for the Defence of Human Rights, Amnesty International, Freedom House, Health Right International and others that effectively operate in Ukraine. They not only react to concrete facts of a resonance violation of human rights, but also carry out systematic monitoring of the effectiveness of human rights activities in different countries of the world.

So, Freedom House has published an annual report, Freedom in the World, on the degree of democratic freedoms in countries and disputed territories around the world, since 1972 (in book form in 1978). This report assesses the current state of civil and political rights on a scale from 1 (the most free) to 7 (the least free). These reports are often used by academics and experts to develop new human rights strategies.

\section{CONCLUSIONS}

The generalizations, provisions and conclusions of guaranteeing and protecting human rights and freedoms as a condition of the development of a state governed by a rule of law and a democratic society in the present study will be incomplete without a problem of proper scientific

\footnotetext{
${ }^{39}$ Громадянське суспільство в Україні: сучасний стан, виклики, стратегія модернізації: монограф. У 2 т. / за заг. ред. акад. НАН України Ю.С. Шемшученка та акад. НАПрН України О.В. Скрипнюка. / T. 1: Загальнотеоретичні та конституційно-правові аспекти розвитку громадянського суспільства в Україні. - К. : Вид-во «Юрид. думка», 2018. - С. 353-354.

${ }^{40}$ Конституція України : прийнята на п’ятій сесії Верховної Ради України 28 червня 1996 року // Відомості Верховної Ради України. - 1996. - № 30. - Ст. 141.
} 
substantiation of human rights activities. It is obvious that the system of guarantees and mechanisms of protection of fundamental rights and freedoms in Ukraine and abroad, which are revealed and disclosed by us, remain certain constitutional and legal attributes, the presence of which does not in itself testify to the exemplary status of observance of human rights and freedoms. The effectiveness of the relevant safeguards and mechanisms of protection is provided through human rights activities, the stages of which, in our opinion, are the followings: (a) affirmation; (b) guarantee; (c) protection; and (d) renewal of constitutional rights and freedoms.

At the same time, despite a large number of thorough works on human rights and freedoms, the issues of human rights protection, as an independent form of legal activity, remain poorly investigated in Ukraine. Although, in recent years, this problem has become increasingly the subject of attention of lawyers. For example, P. Kornienko wrote that:

'...under the constitutional bases of human rights activities in Ukraine should be understood first and foremost purposeful and structured legal activity of state authorities and local self-government bodies, their officials, as well as civil society and business institutes for protection and restoration of human rights and freedoms approved and guaranteed by the Constitution of Ukraine ...."41.

It is clear that the development of legal science in the field of human rights and freedoms and their protection is now doomed to a paradigm shift: from descriptive (narrative) (history and empirical base of the present) and statement of attributes (the constitution and laws, the system of bodies authorized to ensure human rights) to the justification of the latest doctrine of human rights activities, which should be established as a priority function of the state and society.

\section{SUMMARY}

The research is devoted to the actual problem of guaranteeing and protecting the constitutional rights and freedoms of man and citizen in Ukraine. The article substantiates the fact that in the 21 st century, human rights and freedoms remain the most important value, and the state's ability to create conditions for their effective implementation and

\footnotetext{
41 Корнієнко П.С. Конституційні основи правозахисної діяльності в Україні : монограф. / П.С. Корнієнко. - К. : Видавництво Ліра-К, 2018. - С. 301.
} 
mechanisms of protection in case of violation indicate the maturity of not only the state but also civil society.

It is noted that the guarantees of constitutional human rights and freedoms and the protection of constitutional rights and freedoms are related, but not identical categories. If the guarantees of constitutional rights and freedoms of man are, first of all, is a system of conditions and means for the effective realization of human rights and freedoms, then their protection is an independent form of legal activity, the content of which is the purposeful and systemic activity of the person, society and the state with regard to extrajudicial and judicial protection and the restoration of already violated constitutional rights and freedoms.

The analysis and general description of general and special legal guarantees of human rights and freedoms, as well as the mechanism of their judicial and extrajudicial protection are carried out. Some problems of the theory and practice of human rights activities in Ukraine are considered.

\section{REFERENCES}

1. 13 тисяч: офіційні дані ООН щодо загиблих у війні на Донбасі / Радіо Свобода. [Електронний ресурс]. - Режим доступу : https://www.radiosvoboda.org/a/29792144.html - назва з екрану.

2. Головатий С. Про людські права. Лекції / С. Головатий. - К. : Дух і літера, 2016. - 760 с.

3. Громадянське суспільство в Україні: сучасний стан, виклики, стратегія модернізації: монограф. У 2 т. / за заг. ред. акад. НАН України Ю.С. Шемшученка та акад. НАПрН України О.В. Скрипнюка. / Т. 1: Загальнотеоретичні та конституційно-правові аспекти розвитку громадянського суспільства в Україні. - К. : Вид-во «Юрид. думка», 2018. - 676 с.

4. Заворотченко Т. М. Конституційно-правові гарантії прав i свобод людини і громадянина в Україні: Автореф. дис. ... канд. юрид. наук. - К., 2002. - 19 с.

5. Загальна декларація прав людини : прийнята та проголошена резолюцією Генеральної Асамблеї ООН від 10 грудня 1948 року № 217 А (III) // Офіційний вісник України. - 2008. - № 93. - Ст. 3103.

6. Конвенція про захист прав людини і основоположних свобод від 4 листопада 1950 року : ратифікована Законом України від 
17 липня 1997 року № 475/97-ВР разом 3 першим протоколом та протоколами № 2, 4, 7 та 11 // Відомості Верховної Ради України. 1997. - № 40. - Ст. 263.

7. Конвенція про ліквідацію всіх форм дискримінації жінок від 18 грудня 1979 року : ратифікована УРСР 24 грудня 1980 року (із застереженням) // Международные акты о правах человека. Сборник документов. - М. : НОРМА-ИНФРА-М, 1998. - С. 266-280.

8. Конвенція про права дитини : 20 листопада 1989 року (редакція зі змінами, схваленими резолюцією 50/155 Генеральної Асамблеї ООН від 21 грудня 1995 року) // Зібрання чинних міжнародних договорів України. - 1990. - № 1. - Ст. 205.

9. Конституція України : прийнята на п'ятій сесії Верховної Ради України 28 червня 1996 року // Відомості Верховної Ради України. 1996. - № 30. - Ст. 141.

10. Корнієнко П.С. Конституційні основи правозахисної діяльності в Україні : монограф. / П.С. Корнієнко. - К. : Видавництво Ліра-К, 2018. - 360 с.

11. Міжнародна конвенція про ліквідацію усіх форм расової дискримінації від 7 березня 1966 року : ратифікована Президією Верховної Ради Української РСР 21 січня 1969 року // Международные акты о правах человека. Сборник документов. - М. : НОРМА-ИНФРА-М, 1998. - С. 138-148.

12. Міжнародний пакт про громадянські і політичні права від 16 грудня 1966 року : ратифікований Указом Президії Верховної Ради УРСР від 19 грудня 1973 року № 2148-VIII (3 двома факультативними протоколами) // Международные акты о правах человека. Сборник документов. - М. : НОРМА-ИНФРА-М, 1998. C. 53-76.

Міжнародний пакт про економічні, соціальні і культурні права від 16 грудня 1966 року : ратифікований Указом Президії Верховної Ради УРСР від 19 грудня 1973 року № 2148-VIII // Международные акты о правах человека. Сборник документов. - М. : НОРМАИНФРА-М, 1998. - С. 44-52.

14. Парижська кліматична угода, прийнята 12 грудня 2015 р. // Відомості Верховної Ради України. - 2016. - № 35. - Ст. 595. 
15. Про адвокатуру та адвокатську діяльність : Закон України від 5 липня 2012 р. // Відомості Верховної Ради України. - 2014. № 50-51. - Ст. 2057.

16. Про внесення змін до Конституції України (щодо правосуддя) : Закон України від 2 червня 2016 р. // Голос України. 2016. - № 118 (від 29.06.2016).

17. Про гарантії держави щодо виконання рішень суду: Закон України від 5 червня 2012 р. // Офіційний вісник України. - 2012. №. 49. - Ст. 1919.

18. Про Національну поліцію : Закон України від 2 липня 2015 р. // Відомості Верховної Ради України. - 2015. - № 40-41. - Ст. 379.

19. Про Уповноваженого Верховної Ради України 3 прав людини» від 23 грудня 1997 р. // Відомості Верховної Ради України. - 1998. - № 20. - Ст. 99.

20. Пушкіна О. В. Конституційний механізм забезпечення прав людини і громадянина в Україні: проблеми теорії і практики: Автореф. дис. ... док. юрид. наук. - Х., 2008. - 48 с.

21. Стаття 8 Конвенції про захист прав людини i основоположних свобод: стандарти застосування при здійсненні правосуддя / Н. Ахтирська, В. Філатов, Т. Фулей, Х. Хембах. - К. : Істина, 2011. - $200 \mathrm{c}$.

22. Токвіль А. де. Про демократію в Америці. У двох томах / А. де Токвіль ; пер. 3 фр. Г. Філіпчука та М. Москаленка : передм. А. Жардена. - К. : Вид. дім «Всесвіт», 1999. - 590 с.

23. Федоренко В.Л. Конституційне право України : підручник ; До 20-ої річниці Конституції України та 25-ої річниці незалежності України / В.Л. Федоренко. - К. : Вид-во «Ліра», 2016. - 616 с.

24. Федоренко В.Л. Конституціоналізм і революції / В.Л. Федоренко // Право України. - 2018. - № 4. - С. 64-93.

25. Хартия основных прав Европейского Союза. [Електронний pecypc]. - Режим доступу : http: zakon5.rada.gov.ua/laws/show/ 994_524 - назва 3 екрана.

26. Щорічна доповідь Уповноваженого Верховної Ради України 3 прав людини про стан додержання та захисту прав і свобод людини і громадянина в Україн. - К., 2015. - 551 с.

27. Щорічна доповідь Уповноваженого Верховної Ради України 3 прав людини про стан додержання та захисту прав і свобод людини 
і громадянина в Україні. - К. : Вид.-поліграф. центр «Київськ. ун-т», 2018. -134 c.

28. «Я маю право!» / офіційний веб-сайт Міністерства юстиції України. [Електронний ресурс]. - Режим доступу : https://pravo.minjust.gov.ua/ua - назва з екрану.

29. Fedorenko W. Efektywność ochrony praw i wolności człowieka w Ukrainie: historia, współczesność, perspektywy / W. Fedorenko // Uniwersalny i regionalny wymiar ochrony praw człowieka. Nowe wyzwania - nowe rozwiązania. - T. 3. - Warszawa: Wydawnictwo Sejmowe, 2014. - S. 803-806.

30. Fedorenko W. Problem ochrony praw człowieka w warunkach rewolucji oraz konfliktów wojennych / W. Fedorenko // Ochrona praw człowieka w wymiarze uniwersalnym. Akcjologia - instytucje - nowe wyzwania - praktyka. Red. naukowa J. Jaskiernia, K. Sprzyszak. - Toruń: Wydawnictwo Adam Marszałek, 2017. - S. 73-79.

\section{Information about the authors:} Fedorenko V. L.

Doctor of Law, Professor, Director of the Scientific\&Research Center of Forensic Expertise on Intellectual Property of the Ministry of Justice of Ukraine, Honored Lawyer of Ukraine, Forensic Expert of the Higher Qualification Class 26, L. Ukrainka Boulevard, Kyiv, 01133, Ukraine fedorenko900@gmail.com ORCID 0000-0001-5902-1226 